\title{
A New Type Of Online Measurement SYSTEM FOR RESISTANCE WELDING
}

\author{
BOLle, J.; BLIEDTNER, J.; BUERGER, W.; \\ FABER, W. \& ZWEINERT, K.
}

Abstract: Resistance welding is still widely used in carbody production. The character of the measurements demonstrated here is to detect the spot weld's quality by regarding the dynamic strain properties of the spot welding gun during the welding process. With this setup an online diagnosis and simultaneously working quality supervision and parameter regulation is possible. As the quality of each single spot weld can be documented online the whole system has a forseeable future in the automotive sector.

Key words: Process control, restistance welding, online quality evaluation, automation
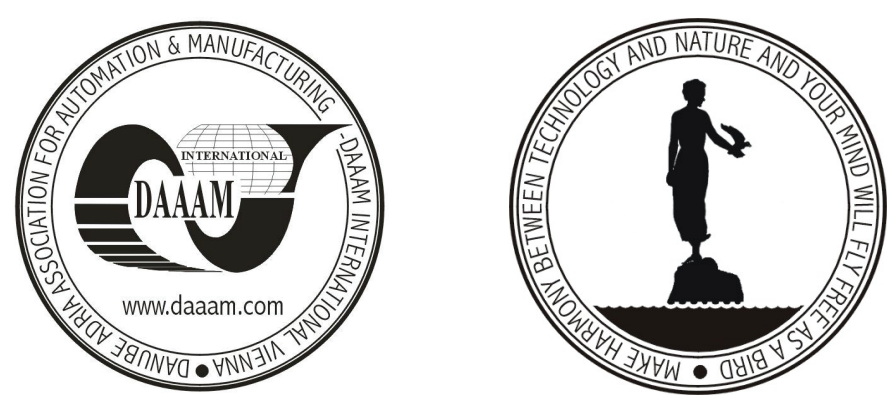

Authors' data: Prof. Dr. Bolle, B., Prof. Dr. Bliedtner, J.; Prof. Dr. Buerger, W., Prof. Dr. Faber, W., Prof. Dr. Zweinert, K., University of Applied Sciences, Jena; MSC Ltd., Halle, Germany

This Publication has to be referred as: Bolle, J.; Bliedtner, J.; Buerger, W.; Faber, W. \& Zweinert, K. (2006). A New Type of Online Measurement System for Resistance Welding, Chapter 07 in DAAAM International Scientific Book 2006, B. Katalinic (Ed.), Published by DAAAM International, ISBN 3-901509-47-X, ISSN 1726-9687, Vienna, Austria

DOI: $10.2507 /$ daaam.scibook.2006.07 